\title{
The Possible Role of USA in Balochitan Issue and its Social- cultural Implications(A Historical Perspective)
}

\author{
Shahida Ishaque', Adil Kasi \\ Muhammad Asif ${ }^{3}$ Abdul Qadir ${ }^{4}$
}

\begin{abstract}
The concept of foreign policy is directly related to interactions one state with international community. Whereas the role of an individual (political leader) always remained controversial. In this regard statements have come from different people. Some analysts argue that the foreign policy framed on any personal capacity by an individual has minor importance in the determination process of foreign policy. Which others believe that is the major important thing.Moreover, the aim of researcher in this paper is to describe thePosition of United States of America in Pakistan in general and Balochistan specifically to analyze the hurdles in ways of cultural and political development of the focused area.Furthermore, the researcher used systematic methodology of comparative and qualitative analysis, while approaching both primary and secondary data. The findings in this research work directly approach the foreign policy of Pakistan with special reference to Pakistan's relations with United state of America and its socio-cultural impicsations on Balochistan.
\end{abstract}

\footnotetext{
${ }^{1}$ Mphil Scholar, Department of International relations, University of Balochistan, Quetta.

${ }^{2}$ Associate Professor, Department of Political Science, University of Balochistan, Quetta.

${ }^{3}$ Lecturer, Department of History, University of Balochistan, Quetta.

${ }^{4}$ Assistant Professor,Department of International relations, University of Balochistan, Quetta.
} 
Key words:British Raj, Annexation, Strategic Location, Diplomacy, arbitration, bordering state, socio- cultural,etc.

\section{Introduction:}

Balochistan is one of the four province of Pakistan located in the southwestern region of the country. At the eve of independence of independent countries Balochistan previously a princely state under the British Raj to annex with Pakistan in 1948. This issue was interrogated by several separatist factions. And the Bloch have agitated for more autonomy since the creation of Pakistan Balochistan is a vast and resourceful land however have unsuccessful to maintain the pace of socio financial progress and modernity with other fellow nations Currently it is the most awful foodstuff apprehensive province of Pakistan. The separatist activities in this province not in favor of the alliance are somewhat vigorous $^{\text {i }}$ Earliest martial action was launch in Baluchistan in 1948. The Balochistan is moreover a well-known direction for drug bargaining, weapons and missiles smuggling, and human trade. further a short time ago, the separatist clash, Hazara's and Punjabi's have been targeted and killingand misplaced people phenomenon (for that cause the government security agencies are held responsible) has formed a worsen tranquility circumstances in the Baluchistan which stressa sufficientclarification elsewhere the Bloch issue. The brutality of Balochistan's issue become other important on worldwide radar throughout preceding decade after the martial action towards the chief of Bugti people in Baluchistan at that time martial president General Parvez Musharraf. Although, the divergence seem to obtain a different revolve at diplomatic point later than the current another investigation taking place the concern of Baluchistan by the United States council during Feb $2012^{\mathrm{ii}}$. 
This paper is an effort to give answers to the queryon the potential role of United States of America to work as arbitration in the conflict among Balochistan and innermost Govt. of Pak.narrate in brief concerning the clash history, this paper examine the United States place androle during the history and currently of Pakistan and subsequently base on that examination try to predictwhether the United States of America can come forward as greatest third revelry (mediator) in the selected issue. Withinworldwide factor, the province is significant as it shares 900-kilo meter border towards Iran and connected with Afghanistan through Durand line.

The first wave of Afghan refugee to Balochistan during the Soviet war in Afghanistan, areidentified as "Quetta Shoora" (which is composed of the leaders of the Afghan Taliban and believe to be based in the city of Quetta in the Balochistan)And United States Govt. on evidence has accuse Balochistan Shoora been engaged militants inAfghanistan. The story of monetary and social backwardness of the Bloch and Balochistan is a multifarious conundrum.Behind opposinggroup rebellious in Balochistan Pakistan accused India to unrest in region. Iran that is predominately a Shia popular country articulate hesitation not in favor of the targeted and killing of Shies (Hazara people) in Balochistan. For Balochistan its strategic location is both blessing and curse ${ }^{\mathrm{iii}}$. Due to complication and difficult situation constantly, examine that divergence is inadequate totwo foremost era states United States of America and Pakistan attach throughout the Afghanistan conflict in 1970-1980'sand United States of America's commitment through Pakistan while colleague to fighting not in favor of terrorism after $9 / 11$. 


\section{Position of United States of America in Pakistan (An overview)}

The United States of America is by no means professed as a companion during era as a result of nearly everyone of the Pakistani's. "Friends not Masters" General A.K is the writer of book, "In the Line of flames by General Parvez Musharraf", and "Reconciliation: Islam, Democracy and the West" the writer of the book is Benazir Bhutto relinquish thecomprehensive explanation and analysis on to United States of America's conflicting strategy toward Pakistan. In keeping with the view of all these writer's relations of Pakistan with United States had by no means taking place on trusted root.

Pak- UnitedStates of America comes nearer during 1950, while the first P.M of Pakistan Liquate Ali Khan visits. The United States of America disregards the call from Union of Soviet Socialist Republic. First martial President General Aube Khan play an imperative responsibility in set up United States-China diplomatic relationship. Although to Aube Khan's dissatisfaction American martial support by no means comes in 1965. Likewise, greatly expected American marine assist by no means arrive at during 26 march 1971 while Pakistan missing his fight inside the East area. Subsequent to1st atomic experiment through India.UnitedStates of America understand the threat of weaken the state and under pressure Pakistan just beforediscard it is atomic .Although, contained in a smaller amount at least around the 10 years restore it is relation along withPakistan ${ }^{\text {iv }}$.Pakistan connected by the United States during the cold war era against the soviet union to help the Mujahedeen in Afghanistan to combat the Soviet union.United States of America handled this proxy conflict throughout CIA-assist mujahedeen, who were make available protected shelter in Pakistan in the Zia regime. once the Soviet 
confrontation was finish, definite sanction and financial restrictions were forced by the United States of America on Pakistan .Relations once more bitter once the crumple of the SSR as the United States permitted ban against Pakistan by passing the Pressler amendment which was act out not in favor of Pakistan in favor of its atomic weapon program that startedlater than war with India in 1971.Pakistan once more understood its important position in American geopolitical interest in the region following the attacks of September $11^{\text {th }} 2011$ and the subsequent war on terror. Relation once again strengthened as the United States named Pakistan a major non NATO ally in 2002 towards aggressive grouping which had relations in Afghanistan (plus individual's base in Balochistan) ${ }^{\mathrm{v}}$.

One of the question for the period of 2008 United States new establishment either the international confrontation going on terrorism a victorious policy otherwise a simply discourse. even as antiwarfare feelings in the United States of America were growing, the United State of America Govt. was challenging of Pakistan to act new in this war. During the govt. of military ruler Parvez Musharaf in Pakistan the United States of America's extreme stress on a martial explanation to the activist crisis and the lack of democracy development worn govt. help sequence of plane droning assault FATA and KPK towards that so-called "high profile objective - members of Taliban, Al Qaida" via United States drone attack not just in enormous inhabitants harm other than and provoke public emotions towards the United States Govt.

Pak-United States relations were twisted once again when in the begging of 2011 Raymond Davis central investigation agency agent in Pakistan murdered two Pakistani men in Lahore say that they came to rob him.However, he was later release of the murder charges and was sent to 
the United States and assassination of Osama Bin Laden by United States Navy seals.United States and Pakistan relation plummeted again when 24 Pakistani soldiers were oppressed in a drone attackthrough United States army. Afghan and United States spokespersons declare that the dismissal because of the assault open from the Pakistani side of the border though the Pakistani army involvement Govt. rejected the claims. By cause of the assault Pakistani govt. permit United States military to leave Salala air base that been use to start distasteful on Taliban and combats. Furthermore the Govt. as well stop NATO equipments used for United States ${ }^{\text {vi }}$.

Weather the United States leverage itself as Mediator? Considering through over discussion, the current taken notice of United States parliament subcommittee component towards problem of Balochistan done extremely small for Baloch Patriot factor. Although this trial is apparent designed for the reason that ethical success through Baloch nationalists, Pakistani official and ordinary Govt. participants plus opponents have critically destined similar idea declare it intrusion towards interior matter of Pakistan.

However,that's fairly obvious United States govt. doesn't benefit from confidence base relationship moreover by the Govt. of Pakistan, arm Forces, or else through the ordinary political resistance party.Pakistan's canonical group, owing to their straight and roundabout help towards Pakistani Taliban, against United States Govt. And survivor of air strikes is towards the United States army owing for the safety desecration. The majority of the Shia sets contain empathy for Iranian Govt. are towards the United States strategy owing to its position towards Iran.

The majority of the United State involvement inside Pakistan as well as it is bordering states.therefore, observelike effortintended to rule 
somewhat and get the worldwide harmony. HatingUSA feelings within the country won't simply agree to the United States position here to handle specific problem associated toward autonomy of Balochistan ${ }^{\mathrm{vii}}$. In addition, the United States position while great influence and third party in the inconsistency of Balochistan could have authority for some Balochi faction other than not for other developing performer in the region.

Theoretically talking yet that United States were to be there a third revelry mediator, the faith insufficient among mutually the revelry of disagreement is furthermore serious to verify the probability of arbitration sequence. Equally the independent and martial administration has beenduring this situation of rejectionissueof Balochistan meant for extensive period. It's just in recent times as Pakistan People's Party govt. announces AHBP (starting of appreciation and civil privileges of Balochi people). However extended environment of issue plus confidence insufficiency towards inner govt. have stop the improvementof getting several factual decisions on that stage. The massive presence of Pakistan army here Balochistan area plus misplaced people matter are the obstacle in process of political dialogue. Therefore United States can't wait for equally the party just before meet taking place table to talk on United State's role otherwise his stance ${ }^{\text {viii }}$.

In addition to the United States be able tonot go for any arbitrary policy to struggle the central govt. of Pakistan on the matter of Balochistan. There is possibility tounwelcome third revelry arbitration will not conduct harmony other than be able to weaken the entire region. Although, financial help or its unavailability(or yet financial ban) could be the simply "stick and carrot" come up to United States for leadharmony into region.,Although a few bans could give an justification to civilian and 
martial management of Pakistan to end every hold up towards their conflict on terror ${ }^{\text {ix }}$.

\section{Implications:}

It cannot be denied that United States of America have several interests in Pakistan, due to territory of Balochistan. And it is also an historical fact that situations in Afghanistan have direct relations with Pakistan and have always affected Pakistan. Implications are of several types but here some socio-cultural implications are discussed as;

- The culture of Tribalism is converted in economic rich political system. Whereas all societies of Balochistan became fragmented in separate ethnic groups.

- The culture of peace, prosperity and hospitality became changed into culture of war, terrorism and extremism.

- Resources become a sources of leadership, which leads to decline in political culture instead of political development.

\section{Conclusion:}

Analyzing ongoing regional circumstances and Pakistan-United States relation,almost it is definite to United States cannot be the third party to determine Baluchistan problem. some participation of United States would more upset the reason of harmony in Balochistan as the United States participation would be professed while a maintain to rebellious by Pakistani govt. supposedly talk about, the regional harmony could go for reinstate throughout a great political power or third performer involvement, when it tries to alter any potential or purpose of equally the parties concerned in the issue. However, presentcircumstances close to several regions issue to clash to utilize harmony policies favorably. These 
circumstances comprise the existence of great powers as hegemonic rule intodomain.

while analyzing for this circumstances by means of reverence toward Balochistan, the United States had on no account be there while hegemonic influence into the region. Indeed, the United States concern in the region has reserved on varying and as a result its strategy to this region. The thought of regional logical condition also finds flawed because of absence of faith between the three mainactors, PakAfghanistan-Iran, plus among the atomic power neighbors, Pak-India. And 3rd situation on conjugal stage is moreover haven't maintain through self government, while unluckily the moderate democratic state is furthermore detained captive toward a variety of ethnic nobles in Balochistan.

The safety problem in Balochistan, cannot permit United States to obtain some act with power because this clash will increase provoke from one boundary to a further at once. But altogether United States needs to utilize extra mechanism to interfere, it requires containing included support on better amount through the countries bordering Pakistan. However devoid offull help of other bordering state, some step by United States to interfere into disagreement will not be professed as a very soon and reasonable attainment. 


\section{REFERENCES:}

${ }^{1}$ Alok, B. (2006). Balochistan:Continuing Violence and Its Imlications. Strategic Analysis 30(1), 46-63.

${ }^{2}$ Benjamin, M. (2005). When and how Regions become Peacful :Potential Theortical Pathway to Peace. International studies Review 7 (2) , 229-267.

${ }^{3}$ Cheema, G. (2010). Intra-State Conflicts and Development Strategies:The Baloch Insurgencyin Pakistan. Pacific Basin Research Center,Soka Univeristy of America;working paper series, pp. 1-40.

${ }^{4}$ Findley G Michael, T. K. (2006). Rethinking Third Party Interventions Into civil War:AnActor Centric Approach. The Journal of Politics 68(4) , 828-837.

${ }^{5}$ International Crisis Group. (2007, October 22). Pakistan:The forgotten Conflict InBalochistan. Asia Briefing No 69 , pp. 1-15.

${ }^{6}$ Johnson.H Thomas and Mason M, C. (2008). No sign untill the burst of Fire Understanding the Pakistan-Afghansitan Frontier. International security $32(4), 41-77$.

${ }^{7}$ Marieke, K. (2002). Great Power Mediation:Using Leverage to Make Peace? In J. (.Bercovitch, The Range of Mediation Experience (pp. 127140). Studies in internationalMediation,London:Palgrave.

${ }^{8}$ Suleri Abid, S. B. (2010). Natural Resources:Blessing or Curse. Sustainable Development Policy Insitute: Working Paper Series 115, pp. $1-20$

${ }^{9}$ Schneckner, U. (2008). Third Party Involvement in Self-dtermination Conflicts. In W. M.(editors), Settling Self-Determination Disputes:Complex Power -Sharing in Theory andPractice (pp. 467-499). Netherlands: Brill Netherlands 